\title{
Marisediminicola antarctica gen. nov., sp. nov., an actinobacterium isolated from the Antarctic
}

\author{
Hui-Rong Li, Yong Yu, Wei Luo and Yin-Xin Zeng \\ SOA Key Laboratory for Polar Science, Polar Research Institute of China, Shanghai 200136, PR \\ China
}

Correspondence

Hui-Rong Li

lihuirong@pric.gov.cn

\begin{abstract}
Strain ZS314 ${ }^{\top}$ was isolated from a sandy intertidal sediment sample collected from the coastal area off the Chinese Antarctic Zhongshan Station, east Antarctica (69 $29^{\prime} 13^{\prime \prime} \mathrm{S} 76^{\circ} 21^{\prime} 41^{\prime \prime} \mathrm{E}$ ). The cells were Gram-positive, motile, short rods. The temperature range for growth was $0-26{ }^{\circ} \mathrm{C}$ and the $\mathrm{pH}$ for growth ranged from 5 to 10, with optimum growth occurring within the temperature range $18-23{ }^{\circ} \mathrm{C}$ and $\mathrm{pH}$ range 6.0-8.0. Growth occurred in the presence of $0-6 \%(\mathrm{w} / \mathrm{v}) \mathrm{NaCl}$, with optimum growth occurring in the presence of 2-4\% (w/v) NaCl. Strain ZS314 ${ }^{\top}$ had MK-10 as the major menaquinone and anteiso- $C_{15: 0}$, iso- $C_{16: 0}$ and anteiso- $C_{17: 0}$ as major fatty acids. The cell-wall peptidoglycan type was $\mathrm{B} 2 \beta$ with ornithine as the diagnostic diamino acid. The major polar lipids were diphosphatidylglycerol and phosphatidylglycerol. The genomic DNA $\mathrm{G}+\mathrm{C}$ content was approximately $67 \mathrm{~mol} \%$. Phylogenetic analysis based on 16S rRNA gene sequence similarity showed that strain $\mathrm{ZS} 314^{\top}$ represents a new lineage in the family Microbacteriaceae. On the basis of the phylogenetic analyses and phenotypic characteristics, a new genus, namely Marisediminicola gen. nov., is proposed, harbouring the novel species Marisediminicola antarctica sp. nov. with the type strain ZS314 ${ }^{\top}\left(=\mathrm{DSM} 22350^{\top}=\mathrm{CCTCC}^{\mathrm{AB}} 209077^{\top}\right)$.
\end{abstract}

The family Microbacteriaceae was proposed by Park et al. (1993) and emended by Stackebrandt et al. (1997) and Zhi et al. (2009) successively. At the time of writing, the family Microbacteriaceae includes 30 genera. The cell wall peptidoglycan type of the genera Agromyces, Cryobacterium, Curtobacterium, Frigoribacterium, Frondihabitans, Mycetocola, Microbacterium, Microcella, Rathayibacter, Subtercola and Yonghaparkia within the family Microbacteriaceae is B. Recently, a few psychrophilic or psychrotolerant actinobacterial strains belonging to the genera Cryobacterium (Suzuki et al. 1997), Frigoribacterium (Kämpfer et al. 2000) and Subtercola (Männistö et al. 2000) have been described. In this study, we report the characterization of a novel actinobacterium isolated from a sandy intertidal sediment sample collected from the coastal area off the Chinese Antarctic Zhongshan Station, east Antarctica (69 $22^{\prime} 13^{\prime \prime} \mathrm{S}$ $\left.76^{\circ} 21^{\prime} 41^{\prime \prime} \mathrm{E}\right)$. Based on our results, we propose a new genus Marisediminicola gen. nov. The type species, Marisediminicola antarctica sp. nov., is described.

In the laboratory, the sediment samples were dried at $8{ }^{\circ} \mathrm{C}$ in a refrigerator for 2 weeks. Dried sediment (approx. $2 \mathrm{~g}$ ) was diluted with $10 \mathrm{ml}$ sterile (autoclaved) seawater. The diluted sample was vortexed, allowed to settle for $30 \mathrm{~min}$, and $100 \mu \mathrm{l}$ of the resulting solution was further diluted

The GenBank/EMBL/DDBJ accession number for the 16S rRNA gene sequence of strain ZS314 ${ }^{\top}$ is GQ496083.

The cellular fatty acid composition of strain $Z S 314^{\top}$ is available with the online version of this paper.
(1:10) and spread onto Gause Mineral agar 1 plates (Bredholdt et al. 2007) supplemented with $100 \mu \mathrm{g}$ cycloheximide $\mathrm{ml}^{-1}, 50 \mu \mathrm{g}$ nystatin $\mathrm{ml}^{-1}$ and $10 \mu \mathrm{g}$ nalidixic acid $\mathrm{ml}^{-1}$. The plates were incubated at $10{ }^{\circ} \mathrm{C}$ for two months. Strain ZS314 ${ }^{\mathrm{T}}$ was obtained in pure culture after three successive transfers to fresh Bacto marine 2216 agar and stored at $-80{ }^{\circ} \mathrm{C}$ in $20 \%(\mathrm{v} / \mathrm{v})$ glycerol.

The cell morphology of strain ZS314 ${ }^{\mathrm{T}}$ was examined with a Nikon eclipse 80i microscope. The colonial morphology was observed on Bacto marine 2216 agar after 4 days incubation at $15{ }^{\circ} \mathrm{C}$. The effect of different growth temperatures was determined on Bacto marine 2216 agar incubated at $0,4,10,15,20,26,30$ and $37^{\circ} \mathrm{C}$. Plates were incubated for 4 weeks and growth was indicated by visible colonies. The $\mathrm{pH}$ range for growth was determined in Bacto marine $2216 \mathrm{E}$ broth at various $\mathrm{pH}$, adjusted with $\mathrm{HCl}$ or $\mathrm{NaOH}(1 \mathrm{M})$. The requirement for $\mathrm{NaCl}$ was tested in a broth medium containing $\left(\mathrm{l}^{-1}\right) 5 \mathrm{~g} \mathrm{MgCl}_{2}, 2 \mathrm{~g}$ $\mathrm{MgSO}_{4}, 0.5 \mathrm{~g} \mathrm{CaCl}_{2}, 1 \mathrm{~g} \mathrm{KCl}, 5 \mathrm{~g}$ peptone and various concentrations of $\mathrm{NaCl}$ at $\mathrm{pH} 7.5$, adjusted with $\mathrm{KOH}$ (Smibert \& Krieg, 1994). The $\mathrm{pH}$-range and $\mathrm{NaCl}-$ tolerance tests were incubated at $12{ }^{\circ} \mathrm{C}$ for 7 days. Amylase production on Bacto marine 2216E agar after 7 days incubation at $20{ }^{\circ} \mathrm{C}$ was determined as described by Smibert \& Krieg (1994). Except for amylase, substrate utilization patterns and other enzymic activities were tested by using the commercial API 50CH, API 20E, API $20 \mathrm{NE}$ and API ZYM strips (bioMérieux). Cells for inoculation of the API systems were suspended in $3 \%$ sea salts (Sigma). 
Acid production from carbohydrates was determined with API $50 \mathrm{CH}$ strips [3\% (w/v) $\mathrm{NaCl}$ was added to the API 50 $\mathrm{CHB} / \mathrm{E}$ medium]. The API strips were incubated at $12{ }^{\circ} \mathrm{C}$ for 3 weeks. All of the tests were performed in duplicate. Morphological, physiological and biochemical characteristics of strain $\mathrm{ZS} 314^{\mathrm{T}}$ are given in the species description (see below).

Respiratory lipoquinone, polar lipid, fatty acid methyl ester, peptidoglycan structure and DNA G + C content analyses were carried out by the Identification Service of the Deutsche Sammlung von Mikroorganismen und Zellkulturen (DSMZ), Braunschweig, Germany. Respiratory quinones were extracted and purified according to Collins (1985) and were analysed by HPLC (Wu et al., 1989). The cellular polar lipids were extracted and analysed by TLC (Kates, 1986). Cell-wall peptidoglycan was isolated and analysed by the methods of Schleifer \& Kandler (1972), Schleifer (1985), MacKenzie (1987) and Groth et al. (1996). For fatty acid methyl ester analysis, the cell mass of strain $\mathrm{ZS}_{314^{\mathrm{T}}}$ was harvested from Bacto marine 2216 agar plates after incubation at $20{ }^{\circ} \mathrm{C}$ for 1 day. Fatty acid methyl esters were extracted and prepared according to the standard protocol of the MIDI (Microbial Identification) system (Sasser, 1990). Strain ZS314 ${ }^{\mathrm{T}}$ contained MK-10 as the major menaquinone. Diphosphatidylglycerol, phosphatidylglycerol and four unknown glycolipids were detected in the polar lipid extracts of strain $\mathrm{ZS} 314^{\mathrm{T}}$. The peptidoglycan of the isolate belonged to the B2 $\beta$ group (Schleifer \& Kandler, 1972), containing a cell-wall type of \{Gly\} [L-Hsr] D-Glu(Hyg)-Gly-D-Orn (type B6; \{\}, position 1; [ ], position 3). The amino acids found in the cell wall hydrolysate were ornithine, alanine, glycine and homoserine in a molar ratio of approximately $0.8: 2.0$ : 2.6:1.0. The predominant cellular fatty acids of strain $\mathrm{ZS} 34^{\mathrm{T}}$ were anteiso- $\mathrm{C}_{15: 0}(44.44 \%)$, iso- $\mathrm{C}_{16: 0}(26.93 \%)$, anteiso- $\mathrm{C}_{17: 0}(18.73 \%)$ and anteiso- $\mathrm{C}_{15: 1} \mathrm{~A}(6.97 \%)$. The fatty acid profile of strain $\mathrm{ZS} 314^{\mathrm{T}}$ is available as supplementary material in IJSEM Online (Supplementary Table S1). The DNA G $+\mathrm{C}$ content was determined by the HPLC method (Cashion et al. 1977; Mesbah et al. 1989; Tamaoka \& Komagata, 1984) with non-methylated Lambda-DNA (Sigma), Bacillus subtilis DSM 402, Xanthomonas campestris pv. campestris DSM $3586^{\mathrm{T}}$ and Streptomyces violaceoruber DSM 40783 as references. The DNA G $+\mathrm{C}$ content of strain $\mathrm{ZS} 314^{\mathrm{T}}$ was $67.3 \mathrm{~mol} \%$.

DNA was extracted and purified by using a ColumnMate Bacteria gDNA Mini kit (Watson) following the manufacturer's protocol. The 16S rRNA gene was amplified by PCR with two universal primers ( $\mathrm{Li}$ et al., 2009). Sequencing reactions were carried out using an ABI BigDye 3.1 Sequencing kit (Applied BioSystems) and an automated DNA sequencer (model ABI3730; Applied BioSystems). The nearly complete $16 \mathrm{~S}$ rRNA gene sequence $(1480 \mathrm{bp}$ ) of strain $\mathrm{ZS} 314^{\mathrm{T}}$ was submitted to GenBank and EMBL to search for similar sequences using the BLAST algorithm. The sequence was aligned by using CLUSTAL X1.8 (Thompson et al. 1997) with sequences retrieved from the databases. Alignments were manually checked by using the SequentiX alignment editor of
Hepperle (2004). The phylogenetic tree was reconstructed by using the neighbour-joining method with Kimura's twoparameter analysis implemented in the program PHYLIP v. 3.6 (J. Felsenstein, University of Washington, Seattle). The resultant tree topologies were evaluated by bootstrap analysis based on 1000 replicates. Phylogenetic analysis (Fig. 1) including representative members of all 30 genera in the family Microbacteriaceae showed that strain ZS314 ${ }^{\mathrm{T}}$ grouped with the members of the genus Mycetocola supported by relatively low bootstrap values $(\leqslant 26 \%)$. This separate phylogenetic position indicated that strain $\mathrm{ZS} 314^{\mathrm{T}}$ deserved the status of a novel genus. The new isolate showed the highest levels of 16S rRNA gene sequence similarity with species of the genera Frigoribacterium (96.1-96.5\%), Frondihabitans (96.3-96.4\%), Mycetocola (96.2-96.4\%), Subtercola (96.2\%) and Cryobacterium (91.7-94.8\%). The bootstrap analysis indicated no significance in the branching pattern of the lineage comprising the new isolate $\mathrm{ZS} 314^{\mathrm{T}}$ and any previously described generic lineage of this family. Similar topologies were found in the trees generated with the maximum-parsimony and maximum-likelihood algorithms (Felsenstein, 1981).

The characteristics that differentiate strain $\mathrm{ZS} 314^{\mathrm{T}}$ from 11 other genera of the family Microbacteriaceae with B-type peptidoglycan are shown in Table 1 . Based on the phenotypic and phylogenetic evidence, strain $\mathrm{ZS} 314^{\mathrm{T}}$ cannot be placed in any of the 30 genera of the family Microbacteriaceae described at the time of writing and we propose to create a new genus, namely Marisediminicola gen. nov. Strain $\mathrm{ZS} 314^{\mathrm{T}}$ represents the type strain of the type species, Marisediminicola antarctica sp. nov.

\section{Description of Marisediminicola gen. nov.}

Marisediminicola [ma.ri.se.di.mi.ni' co.la. L. neut. n. mare the sea; L. n. sedimen -inis sediment; L. suff. - cola (from L. fem. n. incola) inhabitant, dweller; N.L. fem. n. Marisediminicola marine sediment dweller].

Cells are Gram-positive, motile, short rods. Neither substrate mycelium nor aerial mycelium is formed. Catalase is produced but oxidase is not produced. The cell-wall peptidoglycan belongs to the $\mathrm{B} 2 \beta$ group with ornithine as diamino acid. MK-10 is the major menaquinone. The polar lipids are diphosphatidylglycerol, phosphatidylglycerol and some glycolipids. The main cellular fatty acids are anteiso$\mathrm{C}_{15: 0}$, iso- $\mathrm{C}_{16: 0}$ and anteiso- $\mathrm{C}_{17: 0}$. The $\mathrm{G}+\mathrm{C}$ content of the DNA is approximately $67 \mathrm{~mol} \%$. The type species is Marisediminicola antarctica.

\section{Description of Marisediminicola antarctica sp. nov.}

Marisediminicola antarctica (ant.arc'ti.ca. L. fem. adj. antarctica southern, of the Antarctic, the geographical origin of the type strain).

The morphology of the species and its chemotaxonomic characteristics are the same as described for the genus. Cells 


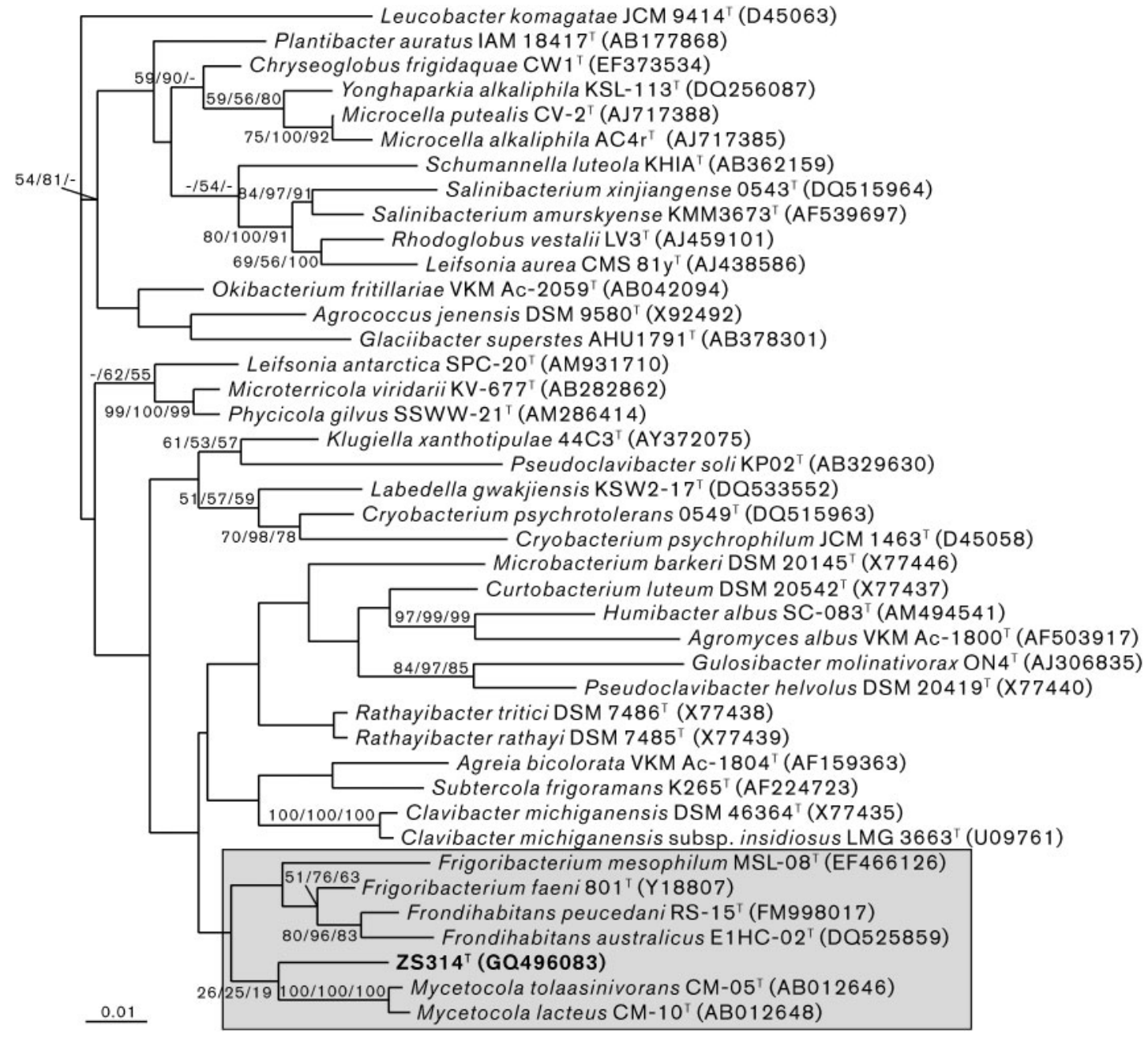

Fig. 1. Phylogenetic relationships of strain $Z S 314^{\top}$ and other members of the family Microbacteriaceae based on $16 \mathrm{~S}$ rRNA gene sequence similarity. The tree was reconstructed by using the neighbour-joining algorithm. The strain characterized in this study is shown in bold type. Numbers at nodes represent levels of bootstrap support (\%) based on maximum-likelihood analysis of 100 resampled datasets, and neighbour-joining and maximum-parsimony analysis of 1000 resampled datasets, respectively (values $\geqslant 50$ are shown). GenBank accession numbers are given in parentheses. The affiliation of strain ZS314 ${ }^{\top}$ to the genera Mycetocola, Frigoribacterium and Frondihabitans is indicated by a shaded grey rectangle. Leucobacter komagatae JCM $9414^{\top}$ (D45063) was used as an outgroup. Bar, $1 \%$ sequence divergence.

are short rods with sizes of $0.2-0.3 \mu \mathrm{m} \times 0.7-0.9 \mu \mathrm{m}$. Colonies are light-yellow, smooth, circular and convex with entire margins after 4 days at $15{ }^{\circ} \mathrm{C}$ on Bacto marine 2216 agar. Produces catalase, and is negative for oxidase activity. Growth occurs at $0-26{ }^{\circ} \mathrm{C}$ and $\mathrm{pH} 5.0-10.0$, with optimum growth occurring in the temperature range 18 $23{ }^{\circ} \mathrm{C}$ and $\mathrm{pH}$ range $6.0-8.0$. Growth occurs in the presence of $0-6 \%(\mathrm{w} / \mathrm{v}) \mathrm{NaCl}$, with optimum growth occurring in the presence of $2-4 \%(\mathrm{w} / \mathrm{v}) \mathrm{NaCl}$. Positive for hydrolysis of para-nitrophenyl- $\beta$-D-galactopyranoside and aesculin. Neither reduction of nitrate nor production of hydrogen sulfide occurs. Indole production and the Voges-Proskauer reaction are negative. Tests for leucine arylamidase, valine arylamidase and naphthol-AS-BI-phosphohydrolase are positive. Cells are weakly positive for the activities of cystine arylamidase, esterase (C4) and esterase lipase (C8). Arginine dihydrolase, lysine decarboxylase, ornithine decarboxylase, urease, tryptophan deaminase, gelatinase, trypsin, amylase, alkaline phosphatase, acid phosphatase, lipase (C14), $\alpha$-galactosidase, ortho-nitrophenyl- $\beta$-D-galactopyranosidase, $\beta$-glucuronidase, $\alpha$-glucosidase, $\beta$-glucosidase, $\quad N$-acetyl- $\beta$-glucosaminidase, $\alpha$-mannosidase, $\alpha$ fucosidase and $\alpha$-chymotrypsin are negative. Only aesculin is utilized as a sole carbon source (as determined using API $50 \mathrm{CH}$ strips). Acid is not produced from a wide variety of carbohydrates other than aesculin. The predominant 


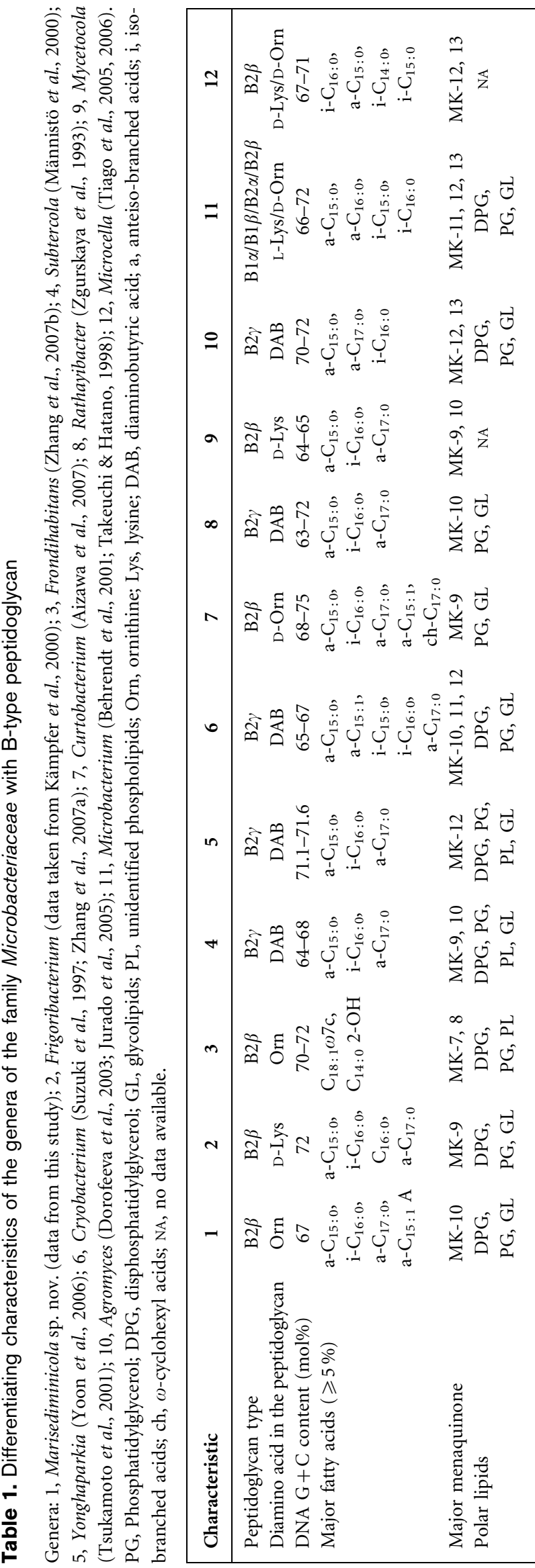

cellular fatty acids are anteiso- $\mathrm{C}_{15: 0}$, iso- $\mathrm{C}_{16: 0}$, anteiso$\mathrm{C}_{17: 0}$ and anteiso- $\mathrm{C}_{15: 1} \mathrm{~A}$. The DNA G+C content of the type strain is $67.3 \mathrm{~mol} \%$.

The type strain, ZS314 ${ }^{\mathrm{T}}\left(=\mathrm{DSM} 22350^{\mathrm{T}}=\right.$ CCTCC AB $209077^{\mathrm{T}}$ ), was isolated from a sandy intertidal sediment sample collected from the coastal area off the Chinese Antarctic Zhongshan Station, east Antarctica (69 $22^{\prime} 13^{\prime \prime} \mathrm{S}$ $\left.76^{\circ} 21^{\prime} 41^{\prime \prime} \mathrm{E}\right)$.

\section{Acknowledgements}

We appreciate the assistance of the Chinese Arctic and Antarctic Administration (CAA) which supports the CHINARE 23 field work of this study. We also thank the scientists of the Identification Service of the DSMZ, especially Dr S. Verbarg for the menaquinone and fatty acids analyses, Dr B. J. Tindall for the polar lipids analyses and Dr P. Schumann for determination of $\mathrm{G}+\mathrm{C}$ content of DNA and the analyses of peptidoglycan structure. This work was supported by the National Natural Science Foundation of China (40876097, 30500001, 40806073), Key International S\&T Cooperation Projects (2008DFA20420) and the Polar Strategic Research Foundation of China.

\section{References}

Aizawa, T., Ve, N. B., Kimoto, K., Iwabuchi, N., Sumida, H., Hasegawa, I., Sasaki, S., Tamura, T., Kudo, T., Suzuki, K., Nakajima, M. \& Sunairi, M. (2007). Curtobacterium ammoniigenes sp. nov., an ammonia-producing bacterium isolated from plants inhabiting acidic swamps in actual acid sulfate soil areas of Vietnam. Int J Syst Evol Microbiol 57, 1447-1452.

Behrendt, U., Ulrich, A. \& Schumann, P. (2001). Description of Microbacterium foliorum sp. nov. and Microbacterium phyllosphaerae sp. nov., isolated from the phyllosphere of grasses and the surface litter after mulching the sward, and reclassification of Aureobacterium resistens (Funke et al. 1998) as Microbacterium resistens comb. nov. Int J Syst Evol Microbiol 51, 1267-1276.

Bredholdt, H., Galatenko, O. A., Engelhardt, K., Fjærvik, E., Terekhova, L. P. \& Zotchev, S. B. (2007). Rare actinomycete bacteria from the shallow water sediments of the Trondheim fjord, Norway: isolation, diversity and biological activity. Environ Microbiol 9, 27562764.

Cashion, P., Holder-Franklin, M. A., McCully, J. \& Franklin, M. (1977). A rapid method for the base ratio determination of bacterial DNA. Anal Biochem 81, 461-466.

Collins, M. D. (1985). Isoprenoid quinone analysis in classification and identification. In Chemical Methods in Bacterial Systematics, pp. 267-287. Edited by M. Goodfellow \& D. E. Minnikin. London: Academic Press.

Dorofeeva, L. V., Krausova, V. I., Evtushenko, L. I. \& Tiedje, J. M. (2003). Agromyces albus sp. nov., isolated from a plant (Androsace sp.). Int J Syst Evol Microbiol 53, 1435-1438.

Felsenstein, J. (1981). Evolutionary trees from DNA sequences: a maximum likelihood approach. J Mol Evol 17, 368-376.

Groth, I., Schumann, P., Weiss, N., Martin, K. \& Rainey, F. A. (1996). Agrococcus jenensis gen. nov., sp. nov., a new genus of actinomycetes with diaminobutyric acid in the cell wall. Int J Syst Bacteriol 46, 234239.

Hepperle, D. (2004). SequentiX alignment editor. Distributed by the author. http://www.sequentix.de 
Jurado, V., Groth, I., Gonzalez, J. M., Laiz, L. \& Saiz-Jimenez, C. (2005). Agromyces salentinus sp. nov. and Agromyces neolithicus sp. nov. Int J Syst Evol Microbiol 55, 153-157.

Kämpfer, P., Rainey, F. A., Anderson, M. A., Nurmiaho Lassila, E.-L., Ulrych, U., Busse, H.-J., Weiss, N., Mikkola, R. \& Salkinoja-Salonen, M. (2000). Frigoribacterium faeni gen. nov., sp. nov., a novel psychrophilic genus of the family Microbacteriaceae. Int J Syst Evol Microbiol 50, 355363.

Kates, M. (1986). Techniques of Lipidology, 2nd edn. Amsterdam: Elsevier.

Li, H., Yu, Y., Luo, W., Zeng, Y. \& Chen, B. (2009). Bacterial diversity in surface sediments from the Pacific Arctic Ocean. Extremophiles 13, 233-246.

MacKenzie, S. L. (1987). Gas chromatographic analysis of amino acids as the $N$-heptafluorobutyryl isobutyl esters. J Assoc Off Anal Chem 70, 151-160.

Männistö, M. K., Schumann, P., Rainey, F. A., Kämpfer, P., Tsitko, I., Tiirola, M. A. \& Salkinoja-Salonen, M. S. (2000). Subtercola boreus gen. nov., sp. nov. and Subtercola frigoramans sp. nov., two new psychrophilic actinobacteria isolated from boreal groundwater. Int $J$ Syst Evol Microbiol 50, 1731-1739.

Mesbah, M., Premachandran, U. \& Whitman, W. B. (1989). Precise measurement of the $\mathrm{G}+\mathrm{C}$ content of deoxyribonucleic acid by highperformance liquid chromatography. Int J Syst Bacteriol 39, 159-167.

Park, Y.-H., Suzuki, K., Yim, D.-G., Lee, K.-C., Kim, E., Yoon, J., Kim, S., Kho, Y., Goodfellow, M. \& Komagata, K. (1993). Suprageneric classification of peptidoglycan group B actinomycetes by nucleotide sequencing of $5 \mathrm{~S}$ ribosomal RNA. Antonie van Leeuwenhoek 64, 307313.

Sasser, M. (1990). Identification of bacteria by gas chromatography of cellular fatty acids, MIDI Technical Note 101. Newark, DE: MIDI Inc.

Schleifer, K. H. (1985). Analysis of the chemical composition and primary structure of murein. Methods Microbiol 18, 123-156.

Schleifer, K. H. \& Kandler, O. (1972). Peptidoglycan types of bacterial cell walls and their taxonomic implications. Bacteriol Rev 36, 407477.

Smibert, R. M. \& Krieg, N. R. (1994). Phenotypic characterization. In Methods for General and Molecular Bacteriology, pp. 607-654. Edited by P. Gerhardt, R. G. E. Murray, W. A. Wood \& N. R. Krieg. Washington, DC: American Society for Microbiology.

Stackebrandt, E., Rainey, F. A. \& Ward-Rainey, N. L. (1997). Proposal for a new hierarchic classification system, Actinobacteria classis nov. Int J Syst Bacteriol 47, 479-491.

Suzuki, K., Sasaki, J., Uramoto, M., Nakase, T. \& Komagata, K. (1997). Cryobacterium psychrophilum gen. nov., sp. nov., nom. rev., comb. nov., an obligately psychrophilic actinomycete to accommodate 'Curtobacterium psychrophilum' Inoue and Komagata 1976. Int J Syst Bacteriol 47, 474-478.
Takeuchi, M. \& Hatano, K. (1998). Union of the genera Microbacterium Orla-Jensen and Aureobacterium Collins et al. in a redefined genus Microbacterium. Int J Syst Bacteriol 48, 739-747.

Tamaoka, J. \& Komagata, K. (1984). Determination of DNA base composition by reversed-phase high-performance liquid chromatography. FEMS Microbiol Lett 25, 125-128.

Thompson, J. D., Gibson, T. J., Plewniak, F., Jeanmougin, F. \& Higgins, D. G. (1997). The CLUSTAL_X windows interface: flexible strategies for multiple sequence alignment aided by quality analysis tools. Nucleic Acids Res 25, 4876-4882.

Tiago, I., Pires, C., Mendes, V., Morais, P. V., da Costa, M. \& Veríssimo, A. (2005). Microcella putealis gen. nov., sp. nov., a Grampositive alkaliphilic bacterium isolated from a nonsaline alkaline groundwater. Syst Appl Microbiol 28, 479-487.

Tiago, I., Morais, P. V., da Costa, M. S. \& Veríssimo, A. (2006). Microcella alkaliphila sp. nov., a novel member of the family Microbacteriaceae isolated from a nonsaline alkaline groundwater, and emended description of the genus Microcella. Int J Syst Evol Microbiol 56, 2313-2316.

Tsukamoto, T., Takeuchi, M., Shida, O., Murata, H. \& Shirata, A. (2001). Proposal of Mycetocola gen. nov. in the family Microbacteriaceae and three new species, Mycetocola saprophilus sp. nov., Mycetocola tolaasinivorans sp. nov. and Mycetocola lacteus sp. nov., isolated from cultivated mushroom, Pleurotus ostreatus. Int J Syst Evol Microbiol 51, 937-944.

Wu, C., Lu, X., Qin, M., Wang, Y. \& Ruan, J. (1989). Analysis of menaquinone compound in microbial cells by HPLC. Microbiology [English translation of Microbiology (Beijing)] 16, 176-178.

Yoon, J.-H., Kang, S.-J., Schumann, P. \& Oh, T.-K. (2006). Yonghaparkia alkaliphila gen. nov., sp. nov., a novel member of the family Microbacteriaceae isolated from an alkaline soil. Int J Syst Evol Microbiol 56, 2415-2420.

Zgurskaya, H. I., Evtushenko, L. I., Akimov, V. N. \& Kalakoutskii, L. V. (1993). Rathayibacter gen. nov., including the species Rathayibacter rathayi comb. nov., Rathayibacter tritici comb. nov., Rathayibacter iranicus comb. nov., and six strains from annual grasses. Int J Syst Bacteriol 43, 143-149.

Zhang, D.-C., Wang, H.-X., Cui, H.-L., Yang, Y., Liu, H.-C., Dong, X.-Z. \& Zhou, P.-J. (2007a). Cryobacterium psychrotolerans sp. nov., a novel psychrotolerant bacterium isolated from the China No. 1 glacier. Int $J$ Syst Evol Microbiol 57, 866-869.

Zhang, L., Xu, Z. \& Patel, B. K. C. (2007b). Frondicola australicus gen. nov., sp. nov., isolated from decaying leaf litter from a pine forest. Int J Syst Evol Microbiol 57, 1177-1182.

Zhi, X.-Y., Li, W.-J. \& Stackebrandt, E. (2009). An update of the structure and 16S rRNA gene sequence-based definition of higher ranks of the class Actinobacteria, with the proposal of two new suborders and four new families and emended descriptions of the existing higher taxa. Int J Syst Evol Microbiol 59, 589-608. 